\title{
Nauplius
}

The Journal of The

Brazilian Crustacean Society

This article is part of the tribute offered

by the Brazilian Crustacean Society

in memoriam of Michael Türkay

outstanding contribution to Carcinology

e-ISSN 2358-2936

www.scielo.br/nau

www.crustacea.org.br

Original Article

\section{Experimental predatory behavior of the stone crab Eriphia verrucosa (Forskål, 1775) (Decapoda, Brachyura, Eriphiidae)}

\author{
Marta Pérez-Miguel ${ }^{1}$ iD orcid.org/0000-0002-6285-7515 \\ Pilar Drake ${ }^{1}$ iD orcid.org/0000-0003-3221-1358 \\ Jose A. Cuesta ${ }^{1}$ iD orcid.org/0000-0001-9482-2336 \\ 1 Instituto de Ciencias Marinas de Andalucía (CSIC). Avda. República Saharaui, 2. \\ 11519 Puerto Real, Cádiz, Spain. \\ MP-M E-mail: marta.perez@icman.csic.es \\ PD E-mail: pilar.drake@icman.csic.es \\ JAC E-mail: jose.cuesta@icman.csic.es
}

ZOOBANK: http://zoobank.org/urn:lsid:zoobank.org:pub:01657254-C367-4A6C-

BA5A-75BCE0652C41

\section{Abstract}

Predatory behavior of the crab Eriphia verrucosa (Forskål, 1775) on the oyster Magallana angulata (Lamarck, 1819), the mussel Mytilus galloprovincialis Lamarck, 1819, the limpet Patella depressa Pennant, 1777, the hermit crab Clibanarius erythropus (Latreille, 1818), the gastropod Phorcus lineatus (da Costa, 1778) and the sea urchin Paracentrotus lividus (Lamarck, 1816) was experimentally studied. Taken into account that the sampled population of E. verrucosa was infected with the parasitic barnacle Sacculina eriphiae Smith, 1906, four predator categories were established regarding crab sex and parasite presence: uninfected and infected males and females, respectively.

CORRESPONDING AUTHOR Marta Pérez-Miguel marta.perez@icman.csic.es

SUBMITTED 7 March 2017

ACCEPTED 30 September 2017

PUBLISHED 11 December 2017

Guest Editor

Célio Magalhães

DOI 10.1590/2358-2936e2017033 These four crab categories were fed on the six preys offered, but prey remains suggest that the crab obtains the flesh of each prey using different methods of attack. Irrespective of the prey species, uninfected females consistently presented lower percentages of crab feeding and total consumption. On average, it was found that a significantly higher percentage of crabs feed on $M$. galloprovincialis, $P$. depressa and $P h$. lineatus than on the other three prey species (chi-squared test, $p<0.05$ ). In terms of mean eaten biomass, the preys most eaten were $P$. lividus and $P$. depress a and the least eaten was 
C. erythropus (ANOVA test, $p<0.05$ ). For crabs feeding on M. galloprovincialis and Ph. lineatus there was a significant positive correlation $(p<0.05)$ between the predator size and prey size, as well as between the predator size and total prey consumption. According to these results, potential effects of this top predator on intertidal communities are also discussed.

\section{KEY WORDS}

Predation effect, Sacculina eriphiae, crab feeding, intertidal epibenthos.

\section{INTRODUCTION}

Predation has long been recognized as an important biological force driving community patterns in intertidal rocky shores throughout the world (Paine, 1974; Brazão et al., 2009). Crabs are highly mobile and are known to have an important role in structuring assemblages on rocky shores worldwide (Behrens Yamada and Boulding, 1996; Rilov and Schiel, 2006; Silva et al., 2008; Forsstrom et al., 2015). They are predators of intertidal hard-shelled prey such as limpets, mussels, gastropods and sea urchins (Turra et al., 2005; Silva et al, 2010; Laitano et al. 2013). When they feed on these hard-shelled preys, many crabs are capable of extracting the meat by peeling the shell aperture and thus avoid spending more time and energy in shell crushing (Rossi and Parisi, 1973). Besides this specialization, there are also reports of more generalized behavior in crab feeding, such as a widespread preference for feeding on small-size preys: these are presumably easier to manipulate and crush and hence offer higher net energy gains (Juanes, 1992; Mills et al., 2016). It is therefore important to know the individual prey preference of crab predators in order to better understand their ecological effects on their prey populations and, as a result, on the assemblage composition of intertidal inhabitants.

The stone crab Eriphia verrucosa (Forskål, 1775) is an intertidal crab from the North-Eastern Atlantic, found along coasts from Brittany to Mauritania and in the Azores (Flores and Paula, 2001), and along Mediterranean coasts (d'Udekem d'Acoz, 1999). It is a typically crepuscular-nocturnal crustacean that leaves its shelter shortly before sunset in search of food, and preferentially eats in the vicinity of its shelter, although with brief excursions into adjacent territories for foraging; encounters between individuals during these feeding excursions may lead to aggressive fighting among conspecifics (Rossi and Parisi, 1973). Thus, as for Carcinus maenas (Linnaeus, 1758), Pachygrapsus marmoratus (Fabricius, 1787) and other stone crabs, the abundance of $E$. verrucosa in different intertidal zones may depend on the availability of suitable rock crevices and/or stones for them to use as shelter, as well as of their spacing, since its aggressive behavior prevents the sharing of a common refuge or very close refuges among two or more individuals (Beck, 1995; Flores and Paula, 2001). Additionally, human activity in the intertidal zone may reduce the population of this predator species by antropogenic impact, both direct (capture of crabs as bait and for human consumption) and indirect (overturning of rocks and trampling over crabs and their shelters when walking in these zones) (Flores and Paula, 2001; Smith and Murray, 2005; Brazão et al., 2009). In this sense, the shore of the Gulf of Cadiz (Southwestern of Iberian Peninsula) features long stretches of sandy beaches, which are used by a large numbers of tourists (Brosnan and Crumrine, 1994; Addison et al. 2008). Therefore, human activities can have important impact, on their intertidal communities (Duran and Castilla, 1989; Addessi, 1994) and, more specifically, on E. verrucosa populations.

Eriphia verrucosa is among the aquatic predators of mollusks and sea urchins found in intertidal habitats. Nevertheless, other predators also feed on mollusks and will contribute to overall effects on these preys (Silva et al., 2010). According to Rossi and Parisi (1973), specimens of E. verrucosa carry their prey (especially those of larger dimensions) toward the shelter; then the predator may use the walking legs to subdue and kill their prey without necessarily breaking the shell, or may use its pair of chelae to break the shell by exerting pressure and prying action in the area of the margin of the shell aperture. At the end, the crab removes the flesh 
and discards the empty shell. Eriphia verrucosa is a nonspecific predator of intertidal macroinvertebrates; the main components of its diet are gastropod and bivalve mollusks, urchins, hermit crabs, and polychaetes (Rossi and Parisi, 1973).

Eriphia verrucosa is commonly infected by the rhizocephalan parasite Sacculina eriphiae Smith, 1906. This parasite can settle on the crab cuticle and develops an internal root-like network (known as 'interna') throughout the tissue of the crab. On maturation, the interna grows outside the crab and forms a saclike structure ('externa') containing the reproductive organs of the parasite (Høeg and Lützen, 1995). The externa is located in the reproductive area of the crab. The parasite infects and castrates both sexes of E. verrucosa (Smith, 1906; Høeg, 1995). Moreover, the parasite induces the feminization in male crabs modifying the hormonal system (Rubiliani et al., 1980; Høeg, 1995; Kristensen et al., 2012). Parasites in marine environments can affect the feeding behavior, energy requirement, condition, reproduction and survival of their hosts (Sousa, 1991; Moore, 2002; Mouritsen and Poulin, 2002; Lafferty and Kuris, 2009).

In the present study, we investigate the experimental feeding behavior of males and females of the stone crab E. verrucosa on six different preys. As the studied crab population was infested by $S$. eriphiae, the possible effect of being infected or not by $S$. eriphiae on the crab feeding behavior is also analyzed.

\section{Material and Methods}

\section{Target species and sampling sites}

The main target species of this study was the stone crab E. verrucosa. According to the food habits of this intertidal predator (Rossi and Parisi 1973; Brazão et al. 2009; Silva et al. 2010), six prey species were chosen as potential food items. The oyster Magallana angulata (Lamarck, 1819), the mussel Mytilus galloprovincialis Lamarck, 1819 and the limpet Patella depressa Pennant, 1777 were used in representation of sessile preys, and the hermit crab Clibanarius erythropus (Latreille, 1818), the toothed top shell Phorcus lineatus (da Costa, 1778) and the rock sea urchin Paracentrotus lividus (Lamarck, 1816) as representatives of vagile prey.

Predator and prey individuals for the laboratory feeding experiments were collected at two intertidal rocky habitats of the Gulf of Cádiz, Torregorda and
Santibáñez beaches (approximately $2 \mathrm{~km}$ apart), subjected to semidiurnal mesotides (tidal range 1 to $3.5 \mathrm{~m}$ ). Both sampling sites were located on rocky platforms with stones and rock pools surrounded by sandy beaches. Torregorda is a restricted military area without tourism and shellfish/bait collection; so there is not significant human activity affecting its macroinvertebrate communities and there is a stable population of E. verrucosa inhabiting it. Conversely, rocky assemblages of Santibáñez were exposed to tourism and shellfish/bait collection and E. verrucosa is seldom found currently.

\section{Laboratory feeding experiments}

Predator and prey individuals used in laboratory experiments were collected from field between November 2014 and April 2015. Individuals of E. verrucosa were collected by hand under the stones of the intertidal habitat of Torregorda, whereas prey individuals were collected on stones either from Torregorda and Santibañez intertidal habitats.

Only adult crabs of both sexes (carapace width $>35$ $\mathrm{mm}$ ) in the late inter-moult stage and with undamaged chelae were used in the experiments. As in the studied population there were crabs infected with $S$. eriphiae, four predator categories were established depending on crab sex and $S$. eriphiae infection stage: uninfected female (F); infected female (Fs), uninfected male (M) and infected male (Ms). Only the crabs in which $S$. eriphiae externa was observable were considered as infected crabs. Number and sizes of E. verrucosa individuals used for each predator category and prey species experiments were summarized in Tab. 1.

Before the start of each experiment, crabs were measured (carapace width, CW) with a digital caliper (Tesa Cal IP65, precision $0.01 \mathrm{~mm}$ ) and individually placed into glass aquaria (one individual per aquarium) containing 5 liters of seawater and a piece of polyvinylchloride (PVC) tubes of suitable diameter as crab's refuge. The aquaria had no sediment for avoiding interfere with predation interactions such as giving a shelter to the prey (Blasi and O'Connor, 2016).

Eriphia verrucosa were not fed for $24 \mathrm{~h}$ to standardize the hunger levels and they were allowed to acclimate under light regime for the same period. Each experience started at 8:00-9:00 a.m. with the addition of live 
individuals of a single prey species to each aquarium (Tab. 2). The experiment was carried out under 12L:12D light conditions and concluded after $24 \mathrm{~h}$. At that time, E. verrucosa were removed, and noneaten prey individuals were counted. Prey items were considered consumed when only fragments of the prey's shell or prey's carapace were found.

The size of prey individuals offered to each crab was measured before the start of the experiment. For the six prey species, the shell length was measured as maximum distance along the anterior-posterior axis of the shell (L). In the case of M. angulata, $M$. galloprovincialis and $P$. depressa, due to the variability in the shell shape, the shell length along the dorsalventral axis was also measured $(\mathrm{H})$. The biomass of each eaten prey was derived from its size by using regression lines previously estimated between the size and wet flesh weight of each prey species. For C. erythropus, $P h$. lineatus and $P a$. lividus, a power function was used to related the wet flesh weight with the anterior-posterior length of shell; whereas for $M$. angulata, $M$. galloprovincialis and $P$. depressa wet flesh weight and the product $(\mathrm{P})$ of anterior-posterior and dorsal-ventral lengths of shell were fitted to a lineal model (Tab. 2).

For each of the four sex-Sacculina infestation category, we estimated the percentage of crab feeding (measured as the percentage of E. verrucosa crabs which fed for each prey treatment) and the mean biomass ( $\mathrm{g}$ ) eaten (measured as the average biomass eaten per each individual of $E$. verrucosa crabs for each prey treatment). Differences in the number of crab feeding of each crab category were tested by using the chi-squared test. Differences in mean consumptions were tested by carrying out two-way ANCOVA tests (Factors: crab category and prey species; Covariate: $\mathrm{CW}$ ) and Student-Newman-Keuls a posteriori tests. In the case that interaction effects are not significant in the ANCOVA but the interaction graphic suggested a crab category's consumption pattern related to prey

Table 1. Characteristics of predators used in individual experiment of different prey species. CW, carapace width; No., number of experiments; F, uninfected females; Fs, infected females; M, uninfected males; Ms, infected males.

\begin{tabular}{|c|c|c|c|c|c|}
\hline \multicolumn{3}{|c|}{ Clibanarius erythropus } & \multicolumn{3}{|c|}{ Magallana angulata } \\
\hline No. & Category & Mean CW (range) mm & No. & Category & Mean CW (range) $\mathrm{mm}$ \\
\hline 7 & $\mathrm{~F}$ & $40.6(36.8-46.0)$ & 5 & $\mathrm{~F}$ & $41.8(36.8-48.2)$ \\
\hline 6 & Fs & $45.5(40.9-51.3)$ & 5 & Fs & $45.0(35.5-53.7)$ \\
\hline 8 & M & $50.9(40.0-58.8)$ & 7 & M & $51.9(40.0-58.8)$ \\
\hline 9 & Ms & $51.1(37.9-66.8)$ & 9 & Ms & $49.8(37.9-66.8)$ \\
\hline \multicolumn{3}{|c|}{ Mytilus galloprovincialis } & \multicolumn{3}{|c|}{ Phorcus lineatus } \\
\hline No. & Category & Mean CW (range) mm & No. & Category & Mean CW (range) mm \\
\hline 12 & F & $41.8(37.3-48.2)$ & 8 & F & $40.5(36.8-48.2)$ \\
\hline 8 & Fs & $45.3(35.5-60.0)$ & 6 & Fs & $45.7(39.0-60.0)$ \\
\hline 13 & $\mathrm{M}$ & $51.9(40.0-63.4)$ & 8 & M & $52.2(43.0-58.8)$ \\
\hline 15 & Ms & $50.6(37.9-66.8)$ & 8 & Ms & $50.4(39.2-59.1)$ \\
\hline \multicolumn{3}{|c|}{ Patella depressa } & \multicolumn{3}{|c|}{ Phorcus lineatus } \\
\hline No. & Category & Mean CW (range) mm & No. & Category & Mean CW (range) mm \\
\hline 8 & F & $41.1(36.8-46.0)$ & 8 & F & $40.5(36.8-46.0)$ \\
\hline 9 & Fs & $46.4(40.9-60.0)$ & 8 & Fs & $44.7(35.5-60.0)$ \\
\hline 7 & M & $52.3(43.0-63.4)$ & 10 & M & $53.7(40.0-63.4)$ \\
\hline 8 & Ms & $48.4(39.2-58.5)$ & 13 & Ms & $50.1(40.5-66.8)$ \\
\hline
\end{tabular}

Table 2. For each prey species, mean number ( \pm standard error) of individuals offered to Eriphia verrucosa in laboratory experiments and regression curves expressing the relationship between the size $(\mathrm{L}, \mathrm{P})$ and biomass $(\mathrm{B})$ of prey specimens. $r$, regression coefficient; $\mathrm{B}$, wet flesh weight; L, anterior-posterior length of shell; P, product of the anterior-posterior and dorsal-ventral lengths of shell.

\begin{tabular}{ccc}
\hline Prey species & Number specimens \\
Mean $( \pm \mathrm{SE})$ & Regression curve \\
\hline Clibanarius erythropus & $2.80( \pm 0.26)$ & $\mathrm{B}=0.0001 \mathrm{~L}^{2.4450}$ \\
Magallana angulata & $12.85( \pm 1.18)$ & 0.95 \\
Mytilus galloprovincialis & $3.40( \pm 0.15)$ & $\mathrm{B}=-0.5868+0.0017 \mathrm{P}$ \\
Paracentrotus lividus & $1.60( \pm 0.16)$ & $\mathrm{B}=-0,1600+0.0025 \mathrm{P}$ \\
Patella depressa & $2.47( \pm 0.13)$ & $\mathrm{B}=0,0006 \mathrm{~L}^{3.0302}$ \\
Phorcus lineatus & $3.33( \pm 0.24)$ & $\mathrm{B}=-0,7245+0.0025 \mathrm{P}$ \\
\hline
\end{tabular}


species, one-way (Factor: crab category; Covariate: CW) ANCOVAs were further carried out for each prey species separately. Prior to the statistical analyses, variances were homogenized by log-transforming data. For each of the four sex-Sacculina infected category of E. verrucosa and prey species, the relationship between crab size (CW) and size of individual eaten, as well as the relationship between crab size and crab total consumption, were assessed by means of a linear correlation analysis; the significance of the estimated Pearson correlation coefficient was used to measure the strength of this relationship.

For all statistical test carried out throughout data analysis, a $p \leq 0.05$ value was selected as threshold of statistical significance.

\section{Results}

\section{Characteristics of predators}

The carapace width of males and females of $E$. verrucosa used in experiments ranged between 37.9 and $66.8 \mathrm{~mm}$ and between $35.5 \mathrm{~mm}$ and $60.0 \mathrm{~mm}$, respectively. On average, size of uninfected females was smaller than that of infected females, whereas no differences in size were observed between infected and uninfected males (Tab. 1). Eriphia verrucosa individuals from the four sex-Sacculina infected/non-infected categories all consumed the six preys offered. During the whole experiment one infected male crab died.

\section{Prey remains}

According to the prey remains found in the aquaria, the method by which the crab obtains the flesh of each prey showed several differences (Fig. 1). The shell of the limpet $P$. depressa usually appeared intact or with a small break in the shell edge, although it was sometimes broken in several pieces. Gastropod shells appeared mostly broken in several pieces, either those occupied by the live gastropod $P h$. lineatus or by the hermit crab Cl. erythropus. In the case of bivalves, the shell of $M$. galloprovincialis often appeared partially intact but with the anterior part of the valve broken; whereas for $M$. angulata the valve fixed to the rock remained intact and the free valve was totally destroyed. In contrast, the sea urchin $\mathrm{Pa}$. lividus sometimes appeared reduced to small pieces but sometimes it was only partially broken.

Generally, the soft tissue of attacked prey was completely consumed. The exception was the sea urchin P. lividus whose soft tissues were sometimes not fully eaten (Fig. 1).

\section{Total consumption trends}

Percentage of crab feeding and mean biomass eaten by each individual showed significantly different trends depending on the prey and/or crab category (Fig. 2). In general, a lower percentage of crab feeding and lower biomass consumption were observed for uninfected females than for the other three crab categories. Concerning prey species, a significantly higher percentage of crab feeding was observed when they were offered $M$. galloprovincialis, $P$. depressa or $P h$. lineatus than in presence of the other three prey species. In term of mean eaten biomass per individual, the prey least eaten was the hermit crab $\mathrm{Cl}$. erythropus and the prey most eaten the sea urchin $\mathrm{Pa}$. lividus and the limpet $P$. depressa. The carapace width of crabs (ANOVA covariate) showed a significantly positive effect on the amount of biomass eaten.

When results for each prey were analyzed separately (Fig. 3), the lower percentage of crab feeding and lower biomass consumption of uninfected females was a consistent pattern in respect of all prey species offered, although differences were not always significant.

\section{Predator size versus prey biomass consumption}

When only those crabs that actually ate during trials were included in analyses, there was a significant positive correlation between the predator size (carapace width) and prey size (biomass), as well as between predator size and total prey consumption, for $M$. galloprovincialis and $\mathrm{Ph}$. lineatus (Fig. 4). A relatively high correlation was also observed between predator size and the total consumption and prey size for $\mathrm{Cl}$. erythropus, but due to the low number of crabs feeding on this prey the corresponding correlation coefficients were not statistically significant.

\section{Discussion}

Other large stone crab species, such as the cancrid crab Cancer novaezealandiae (Jacquinot, 1853), are capable of a flexible foraging behavior, which may allow crabs to maximize feeding efficiency depending on the characteristics of the available prey (Creswell and McLay, 1990). Similarly, the crab Danielethus crenulatus (A. Milne-Edwards, 1879), which also 


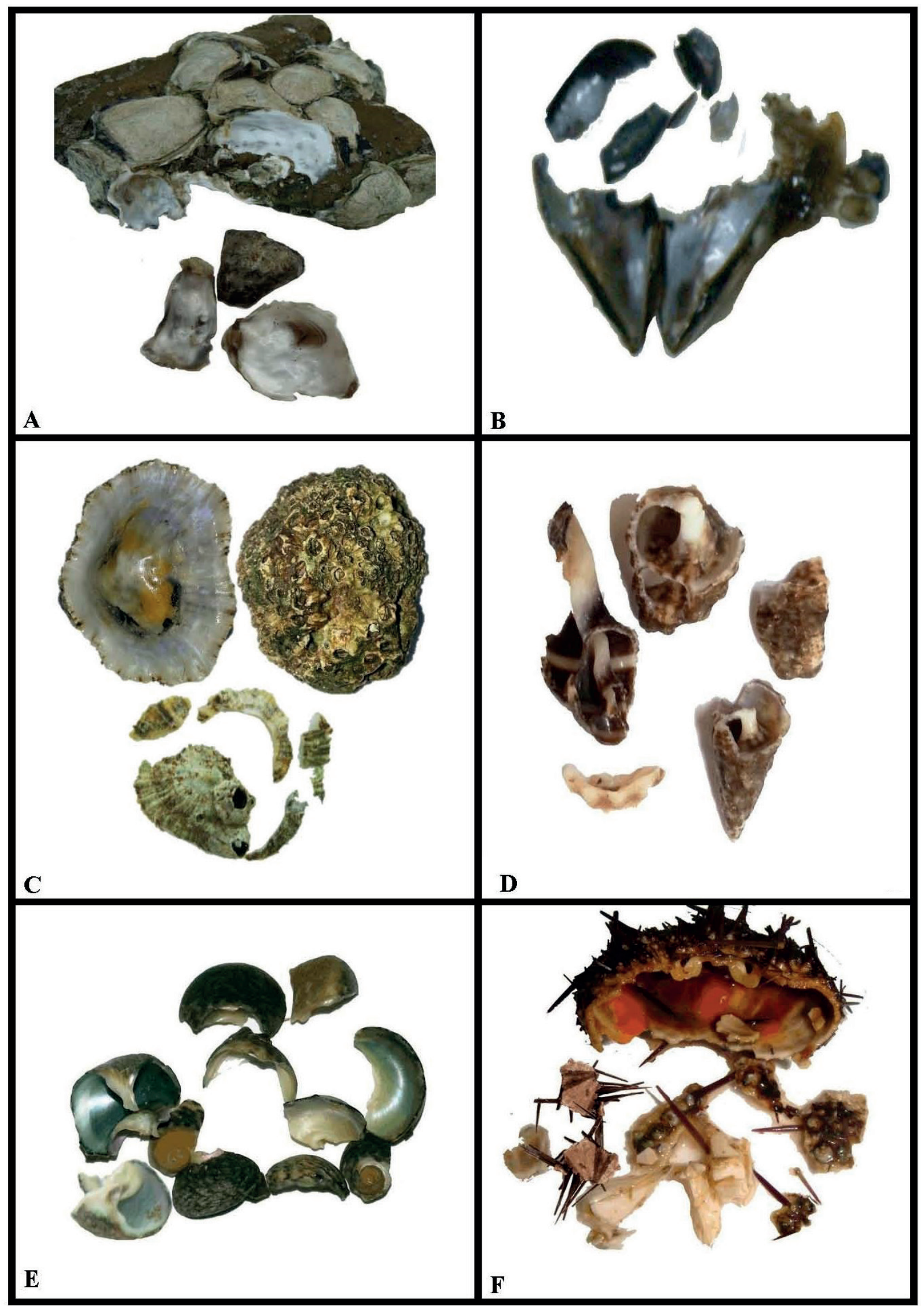

Figure 1. Effect of predation by Eriphia verrucosa on Magallana angulata (A), Mytilus galloprovincialis (B), Patella depressa (C), Clibanarius erythropus (D), Phorcus lineatus (E) and Paracentrotus lividus (F). 

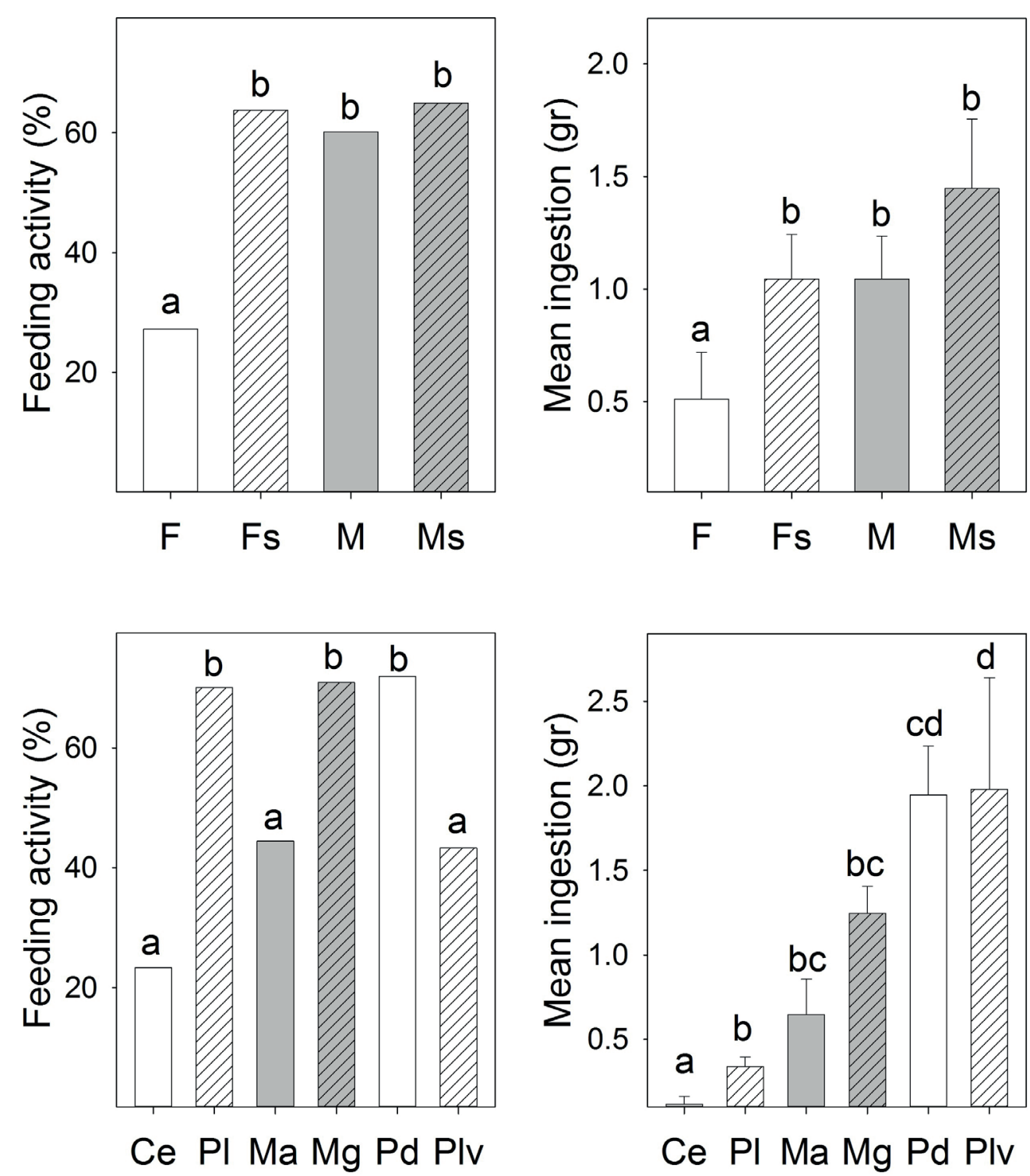

Figure 2. Percentage of Eriphia verrucosa feeding and mean $(+S E)$ consumption (wet weight): for each predator category (top plots) and for each prey offered (bottom plots). Ce, Clibanarius erythropus; Pl, Phorcus lineatus; Ma, Magallana angulata; Mg, Mytilus galloprovincialis; Pd, Patella depressa; Plv, Paracentrotus lividus; F, uninfected females; Fs, infected females; M, uninfected males; Ms, infected males. Different letters show significant difference $(P<0.05)$.

break the shell of prey, attacks effectively and consumes many different sympatric mollusk species, but when faced with a choice it prefers some species over the others (Laitano et al., 2013). Results of the present study also indicated that, although the stone crab E. verrucosa is able to consume all six types of prey offered, the proportion of crab feeding and/or the biomass of prey eaten vary considerably among them: a higher percentage of crab feeding was observed when the mussel M. galloprovincialis, the limpet $P$. depressa or the sea snail $P h$. lineatus were offered, whereas the individual biomass eaten was higher when the prey offered was $P$. depressa, $P a$. lividus and, to a less extent, M. galloprovincialis (Fig. 2). Such discrepancies between the percentage of crabs feeding on a prey and the corresponding average biomass eaten could be related to whether more or less time and effort is required in handling the prey in order to access the edible content of the different shelled or spineprotected prey. In this regard, bivalves were opened more quickly than gastropods, although at small shell sizes time differences were negligible (Creswell and McLay, 1990); if the prey offered are gastropods, a prey preference driven by shell shape and thickness 


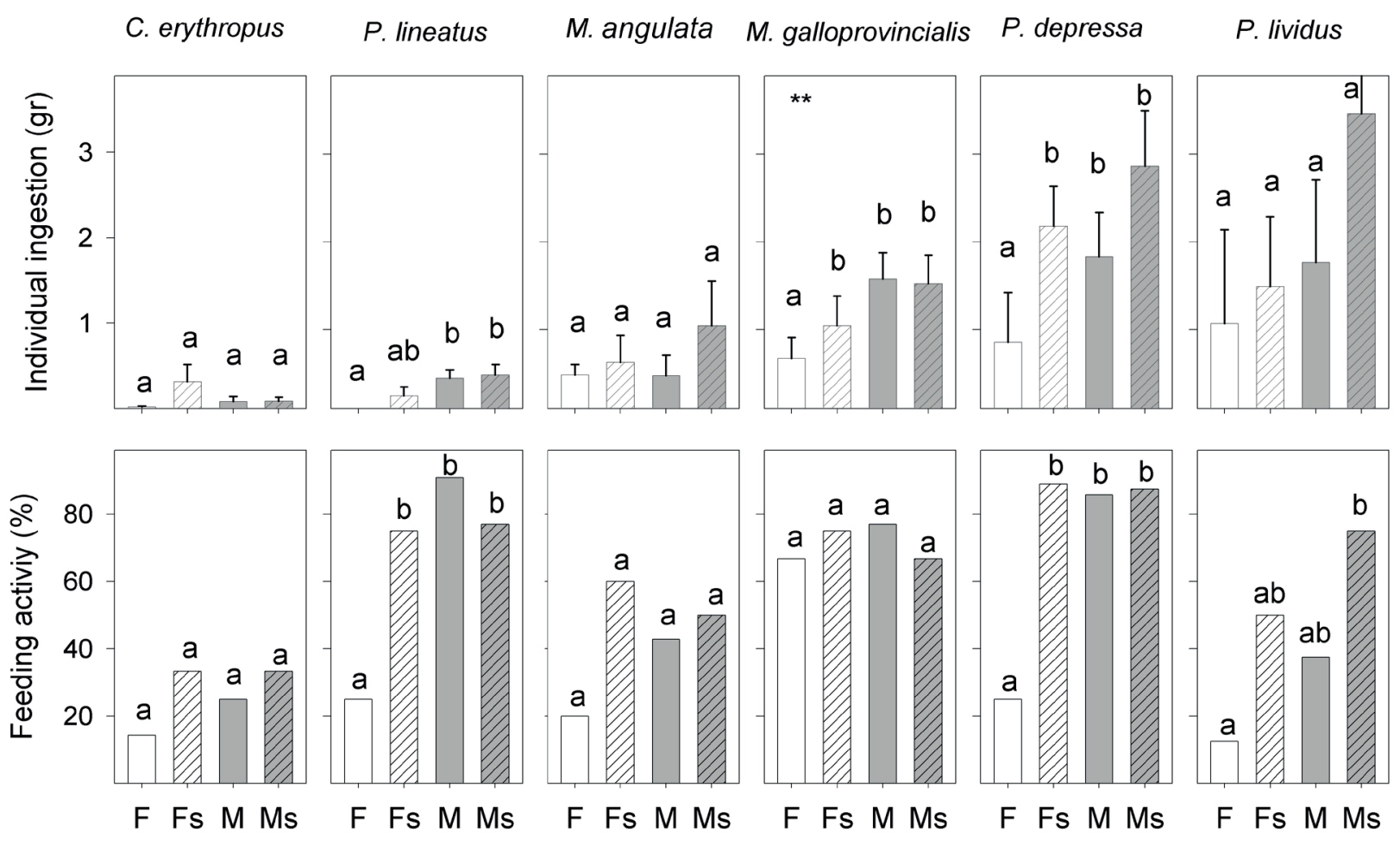

Figure 3. Differences in the percentage of crabs feeding and the mean $(+\mathrm{SE})$ consumption (wet weight) for each prey offered to uninfected females $(F)$, infected females (Fs), uninfected males (M) and infected males (Ms). Different letters show significant difference $(P<0.05)$.

seems to be a common pattern among large stone crab species (Laitano et al., 2013). The shell rugosity of prey was also relevant since crabs cannot easily attach to a shell with smooth surface (Weigand and Plath, 2013).

Likewise, when E. verrucosa was preying on gastropod-shelled prey (sea snails and hermit crabs), the mechanical characteristics of the shell, and hence the accessibility of its contents, seems to be of greater importance than the content itself (Rossi and Parisi, 1973). The trochid-like shell of $P h$. lineatus, for example, is more fragile than that of the cerithiid species such as Cerithium spp. and Nassarius spp. (most of the shells occupied by $\mathrm{Cl}$. erythropus in this study). Hence, the higher average consumption of $P$. depressa and $P a$. lividus suggest easier access to the shelled or spine protected content by crabs preying on these prey versus greater difficulty in the case of gastropod shell protected species, as Ph. lineatus or the hermit crab Cl. erythropus. In fact, despite the relatively small size of the latter two species (Fig. 4), the higher correlation between the crab size and the snail size $(r=0.53$ and 0.51 for $C l$. erythropus and $P h$. lineatus, respectively) seems to reflect the greater difficulty in crushing gastropod shells. Additionally, for small-size species this also means that crabs needed to prey on more items of them to consume a similar biomass, in comparison with large-size prey.

In the neighbouring Portuguese coasts, the spatial distribution of intertidal crabs (such as E. verrucosa) seems to be related to differences in degree of exposure to human collecting activity (Flores and Paula, 2001). Likewise, due to the human extraction of E. verrucosa specimens to use them as bait or for human consume, in the Gulf of Cádiz the species is currently not observed under the stones at some rocky habitats with free access of visitors and shellfish gatherers (as, for instance, Santibáñez beach), whereas it was very abundant at others with restricted human access as the military protected area of Torregorda (Stevčić et al., in press). Top predators as E. verrucosa could play a significant role in structuring intertidal communities (Rilov and Schiel, 2006; Silva et al., 2010). Indeed, using predatorexclusion experiments, Silva et al. (2008) observed a significant reduction of limpet densities when crabs predation was occurring. Conversely, Brazão et al. (2009) failed to detect a significant effect from $E$. 


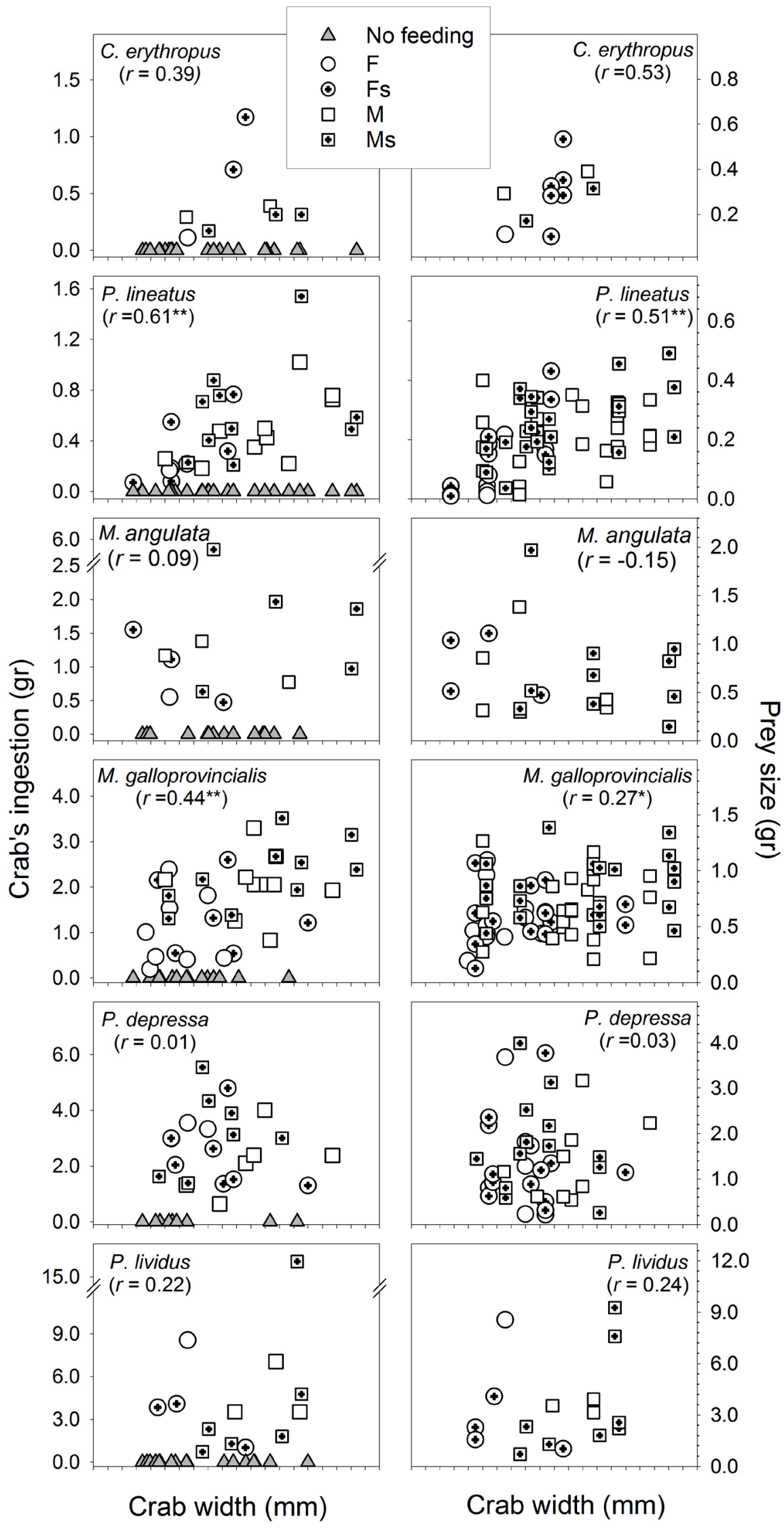

Figure 4. The relationship between crab's size (carapace width) and crab's total consumption (left plots) and prey size (right plots). F, uninfected females; Fs, infected females; M, uninfected males; Ms, infected males. 
verrucosa and other predator crab species on mussel and limpet densities on Portuguese rocky habitats; these authors argued that this could be due to a humandriven reduction of crab predator abundance. Since the invertebrate species offered to E. verrucosa as prey were also collected by local human visitors of the rocky habitats, results of this study suggest a certain overlap in the key role that both "top-predators" (E. verrucosa and Homo sapiens Linnaeus, 1758) can play in structuring the intertidal communities. However, in order to examine such overlap it would be necessary to carry out predator-exclusion experiments at rocky habitats with just one of both predators.

There are some theories claiming that the infection by rhizocephalan cirripeds such as Sacculina spp. produces a general disturbance of the metabolism of the host, especially of the fat metabolism (Hartnoll, 1967). For example, the crab Callinectes rathbunae Contreras, 1930 when is parasitized by the rhizocephalan barnacle Loxothylacus texanus Boschma, 1933 has oxygen consumption from 57 to $139 \%$ higher than uninfected crabs, with a significant metabolic cost associated with the presence of mature L. texanus (cf. Robles et al., 2002). A priori, one might expect that the infected crabs have a stronger predator behavior than those uninfected. Within each sex, crabs presenting externa of $S$. eriphiae showed higher average consumption than crabs not infected (Fig. 2). However, a statistically significant increase in the percentage of crab feeding and consumption was observed only between uninfected and infected females for some prey. Although uninfected females displayed the smallest mean size of tested crab groups, there was no relationship between low percentage of crab feeding and smaller crab size (Fig. 4). Thus, the smallest size of uninfected females should be associated only with the age of the crab (only crabs bearing externa were included in this category). This limited effect of S. eriphiae on its host E. verrucosa agrees with results observed by Larsen et al. (2013) in C. maenas infected with Sacculina carcini Thompson, 1836. However, infected E. verrucosa of both sexes consumed more $P$. depressa and $P a$. lividus, which were the two preys with a significant lower density in the area where E. verrucosa is present (Stevčić et al., in press). We hypothesize that the energy cost of eating the latter two preys could be lower than that of other preys, so the infected E. verrucosa consumes more in order to have a greater energy efficiency to maintain its own fitness and that of the S. eriphiae.

In summary, E. verrucosa consumed all the offered prey confirming that is a generalist predator of intertidal macroinvertebrates. However, the percentage of crab feeding and biomass eaten varied among prey considerably, which suggests a prey preference that could be primarily based on maximizing energy from the potential consumption. Concerning $S$. eriphiae infection, only uninfected females consumed significantly less prey than the other crab groups, suggesting that $S$. eriphiae may have only a limited effect on feeding behaviors of its crab host. We hypothesize that the parasite alters host metabolism but that this alteration is more severe in females.

\section{ACKNOWLEDGEMENTS}

We wish to thank Spanish Ministry of Defense, and especially "Centro de Ensayos Torregorda Instituto Nacional de Técnica Aeroespacial (INTA)” for granting access to Torregorda beach and facilities. Moreover, we thank the help of Antonio Moreno and David Roque from the ICMAN Field Operations Unit (OPECAM) for help in the sampling campaigns. Two anonymous reviewers provided useful comments and corrections that clearly improved this paper. We would also like to show our gratitude to the memory of Prof. Dr. Michael Türkay for a lifetime dedicated to Carcinology, especially for his exceptional work in the knowledge of the European brachyuran fauna. We thank Royston Snart for the linguistic revision of the English text.

\section{RefERENCES}

Addessi, L. 1994. Human disturbance and long-term changes on a rocky intertidal community. Ecological Applications, 4: 786-797.

Addison, P.F.E.; Koss, R.S. and O’Hara, T.D. 2008. Recreational use of a rocky intertidal reef in Victoria: implications for ecological research and management. Australasian Journal of Environmental Management, 15: 169-179.

Beck, M.W. 1995. Size-specific shelter limitation in stone crabs: a test of the demographic bottleneck hypothesis. Ecology, 76: 968-980.

Behrens Yamada, S. and Boulding, E.G. 1996. The role of highly mobile crab predators in the intertidal zonation of their gastropod prey. Journal of Experimental Marine Biology and Ecology, 204: 59-83.

Blasi, J.C. and O'Connor, N.J. 2016. Amphipods as potential prey of the Asian shore crab Hemigrapsus sanguineus: Laboratory 
and field experiments. Journal of Experimental Marine Biology and Ecology, 474: 18-22.

Brazão, S.A.E.; Silva, A.C.F. and Boaventura, D.M. 2009. Predation: a regulating force of intertidal assemblages on the central Portuguese coast? Journal of the Marine Biological Association of the United Kingdom, 89: 1541-1548.

Brosnan, D.M. and Crumrine, L.L. 1994. Effects of human trampling on marine rocky shore communities. Journal of Experimental Marine Biology and Ecology, 177: 79-97.

Creswell P.D. and McLay, C.L. 1990. Handling times, prey size and species selection by Cancer novaezelandiae (Jacquinot, 1853) feeding on molluscan prey. Journal of the Marine Biological Association of the United Kingdom, 140: 13-28.

d'Udekem d'Acoz C. 1999. Inventaire et distribution des crustacés décapodes de l'Atlantique nord-oriental, de la Méditerranée et des eaux continentales adjacentes au nord de $25^{\circ} \mathrm{N}$. Paris, Muséum national d'Histoire naturelle, 383p. (Collection Patrimoines Naturels, 40)

Durán, L.R. and Castilla, J.C. 1989. Variation and persistence of the middle rocky intertidal community of central Chile, with and without human harvesting. Marine Biology, 103: 555-562.

Flores, A.A.V. and Paula, J. 2001. Intertidal distribution and species composition of brachyuran crabs at two rocky shores in Central Portugal. Hydrobiologia, 449: 171-177.

Forsstrom, T.; Fowler, A.E.; Manninen, I. and Vesakoski, O. 2015. An introduced species meets the local fauna: predatory behavior of the crab Rhithropanopeus harrisii in the Northern Baltic Sea. Biological Invasions, 17: 2729-2741.

Hartnoll, R.G. 1967. The effects of sacculinid parasites on two Jamaican crabs. Journal of the Linnean Society of London, Zoology, 46: 275-295.

Høeg, J.T. 1995. The biology and life cycle of the Rhizocephala (Cirripedia). Journal of the Marine Biological Association of the United Kingdom, 75: 517-550.

Høeg, J.T. and Lützen, J. 1995. Life cycle and reproduction in the Cirripedia Rhizocephala. Oceanography and Marine Biology - An Annual Review, 33: 427-485.

Juanes, F. 1992. Why do decapod crustaceans prefer small-sized molluscan prey? Marine Ecology Progress Series, 87: 239-249.

Kristensen, T.; Nielsen, A.I.; Jørgensen, A.I.; Mouritsen; K.N.; Glenner, H.; Christensen, J.T.; Lützen, J. and Høeg, J.T. 2012. The selective advantage of host feminization: a case study of the green crab Carcinus maenas and the parasitic barnacle Sacculina carcini. Marine Biology, 159: 2015-2023.

Lafferty, K.D. and Kuris, A.M. 2009. Parasitic castration: the evolution and ecology of body snatchers. Trends in Parasitology, 25: 564-572.

Laitano, M.V.; Farías, N.E. and Cledón, M. 2013. Prey preference of the stone crab Platyxanthus crenulatus (Decapoda: Platyxanthidae) in laboratory conditions. Nauplius, 21: 17-23.

Larsen, M.H.; Høeg, J.T. and Mouritsen, K.N. 2013. Influence of infection by Sacculina carcini (Cirripedia, Rhizocephala) on consumption rate and prey size selection in the shore crab Carcinus maenas. Journal of Experimental Marine Biology and Ecology, 446: 209-215.

Mills, C.D.; Clark, P.F. and Morritt, D. 2016. Flexible prey handling, preference and a novel capture technique in invasive, sub-adult Chinese mitten crabs. Hydrobiologia, 773: 135-147.

Moore, J. 2002. Parasites and the Behavior of Animals. Oxford Series in Ecology and Evolution Oxford and New York, Oxford University Press, 315p.

Mouritsen, K.N. and Poulin, R. 2002. Parasitism, community structure and biodiversity in intertidal ecosystems. Parasitology, 124: S101-S117.

Paine, R. 1974. Intertidal community structure. Experimental studies on the relationship between a dominant competitor and its principal predator. Oecologia, 15: 93-120.

Rilov, G. and Schiel, D.R. 2006. Trophic linkages across seascapes: subtidal predators limit effective mussel recruitment in rocky intertidal communities. Marine Ecology Progress Series, 327: 83-93.

Robles, R.; Alvarez, F. and Alcaraz, G. 2002. Oxygen consumption of the crab Callinectes rathbunae parasitized by the rhizocephalan barnacle Loxothylacus texanus as a function of salinity. Marine Ecology Progress Series, 235: 189-194.

Rossi, A.C. and Parisi, V. 1973. Experimental studies of predation by the crab Eriphia verrucosa on both snail and hermit crab occupants of conspecific gastropod shells. Bolletino di zoologia, 40: $117-185$.

Rubiliani, C.; Rubiliani Durozoi, M. and Payen, G.G. 1980. Effets de la sacculine sur les gonades, les glandes androgenes et le systeme nerveux central des crabes Carcinus maenas (L.) et C. mediterraneus Czerniavsky. Bulletin de la Société zoologique de France, 105: 95-100.

Silva, A.C.F.; Hawkins, S.J.; Boaventura, D.M. and Thompson, R.C. 2008. Predation by small mobile aquatic predators regulates populations of the intertidal limpet Patella vulgata (L.). Journal of Experimental Marine Biology and Ecology, 367: 259-265.

Silva, A.C.; Silva, I.C.; Hawkins, S.J.; Boaventura, D.M. and Thompson, R.C. 2010. Cheliped morphological variation of the intertidal crab Eriphia verrucosa across shores of differing exposure to wave action. Journal of Experimental Marine Biology and Ecology, 391: 84-91.

Smith, G. 1906. Rhizocephala. Fauna und Flora des Golfes von Neapel, 29: 1-123.

Smith, J.R. and Murray, S.N. 2005. The effects of experimental bait collection and trampling on a Mytilus californianus mussel bed in southern California. Marine Biology, 147: 699-706.

Sousa, W.P. 1991. Can models of soft-sediment community structure be complete without parasites? American Zoologist, 31: 821-830.

Stevčić, C.; Pérez-Miguel, M.; Drake, P.; Tovar-Sánchez, A. and Cuesta, J.A. In press. Macroinvertebrate communities on rocky shores: Impact due to human visitors. Estuarine, Coastal and Shelf Science. doi: 10.1016/j.ecss.2017.11.026

Turra, A.; Denadai, M.R.; Fosca P.P. and Leite, F.P.P. 2005. Predation on gastropods by shell-breaking crabs: effects on shell availability to hermit crabs. Marine Ecology Progress Series, 286: 279-291.

Weigand, A.M. and Plath, M. 2013. Prey preferences in captivity of the freshwater crab Potamonautes lirrangensis from Lake Malawi with special emphasis on molluscivory. Hydrobiologia, 739: 145-153. 